\title{
ReDoC
}

Revista Docência e Cibercultura

\section{ITINERÁRIO TERAPÊUTICO DOS HOMENS TRANSGÊNEROS DA BAIXADA CUIABANA/MT}

\section{THE SEEKING BEHAVIOR OF TRANSGENDERS MEN (ftm) OF THE REGION BAIXADA CUIABANA/MT}

\section{EL TRAYECTO TERAPÉUTICO DE DE LOS HOMBRES TRANSGÉNEROS EN LA REGIÓN BAIXADA CUIABANA/MT}

Rayssa Karla Dourado Porto ${ }^{1}$

RESUMO:

Este trabalho de dissertação está inserido na área das Ciências Humanas no campo da Saúde Coletiva, sua temática envolve a saúde dos homens transgêneros. O sexo biológico das crianças ocupa um lugar central para as suas primeiras relações interpessoais e subjetivas, toda construção imaginária e idealizada dos pais funda-se neste aspecto. Antes mesmo da criança se perceber como um sujeito, a sociedade cis-hétero-normativa dita que deve haver consonância entre sexo biológico, orientação sexual e identidade de gênero. Intriga-nos saber o que as pessoas fazem quando sua identidade de gênero não corresponde ao seu sexo biológico. A discussão teórica sobre gênero fundamenta-se em BEAUVOIR (1967), BUTLER (2003) E LOURO (1997), entre outros. Diante de tal conflito, pretende-se compreender como são tecidas as redes de busca por atendimentos, como fazem para ter acesso à informações e serviços no sistema formal de saúde e, sobretudo, quais são as demandas e dificuldades dos homens transgêneros nesse percurso (KLEINMAN, 1978; SOUZA e PEREIRA, 2016). Parte-se do pressuposto que há barreiras e entraves para o processo transexualizador, devido às questões financeiras, morais e sobretudo geográficas. Os sujeitos da pesquisa são homens que decidiram passar pelo processo transexualizador. É imprescindível pontuar que homens transgêneros nasceram e foram intituladas como "mulheres cisgênero". Ao não se reconhecer com a

\footnotetext{
Submetido em: 09/03/2019

Aceito em: 08/04/2019

Publicado em: 01/06/2019

${ }^{1}$ Mestranda em Saúde Coletiva pela Universidade Federal de Mato Grosso. Graduação em Psicologia. Experiência em Psicologia Clínica.
}

\begin{tabular}{l|l|l|l|l|l|l|} 
(C) Redoc & Rio de Janeiro & v. 3 & n.1 & p. 234 & Jan/Abr. 2019 & e-ISSN 2594-9004
\end{tabular}


identidade feminina buscam passar pela transição para adquirir caracteres masculinos como forma de adequar sua imagem à sua identidade de gênero (ARÁN, 2006; BENTO 2008; LIMA, 2014). Como estratégia metodológica optou-se por entrevistas individuais com roteiro semiestruturado, para assim compreender os caminhos de cuidado que os homens transgêneros percorrem ao decidirem passar pelo processo transexualizador. Após a coleta dos dados será realizada a análise das narrativas e do contexto imbricado nesse: a cultura, a historicidade, a sociedade e a performatividade do sujeito (FOUCAULT, 2017; LANGDON,1999). Assim, pretende-se compreender o drama social (TURNER,1986) dos homens transgêneros no processo de busca pela sua identidade de gênero. Os capítulos que integram o marco teórico são: Gênero e identidade de gênero; Corpo e subjetividade; Atenção à saúde, dificuldades e necessidades; Itinerário terapêutico e Políticas públicas e direitos à saúde. Quando nos deparamos com as situações sobre as dificuldades e entraves para realização do processo transexualizador, percebemos a relevância de estudar e fornecer contribuições específicos sobre essa população para endossar políticas e serviços voltados para transgêneros, transexuais e travestis. Uma das hipóteses que rege a pesquisa é que há preconceito, desinformação, ocorrendo assim a falha no atendimento desses sujeitos pelos profissionais de saúde. Essa questão desperta-nos para a importância de compreendermos o contexto social em que vivem, especialmente por desafiarem a sociedade heteronormativa eles ficam à mercê da violência e do adoecimento mental.

PALAVRAS-CHAVE: Homem Transgênero. Identidade de Gênero. Itinerário Terapêutico. Análise de Narrativas. 